\title{
Using Youtube $\subset$ in the Classroom for the Net Generation of Students
}

\author{
Sumarie Roodt and Dominic Peier \\ University of Cape Town, Cape Town, South Africa
}

sumarie.roodt@gmail.com PRXDOM001@myuct.ac.za

\begin{abstract}
The Net Generation, being the generation born after 1982, are so called as their arrival coincided with the emergence of digital technology such as the internet and PCs. Research suggests that this generation of individuals have different styles of learning due to their comfort with and use of digital technology. Thus, educating and engaging the Net Generation has become a challenge faced by higher education institutions. Various suggestions have been made in order to educate and engage the Net Generation. One of these suggestions has been the use of Web 2.0 elements, such as YouTube, blogs and wikis inside and outside the classroom. This research paper investigates the use of YouTube in the classroom for the engagement of Net Generation students for a $2^{\text {nd }}$ year under-graduate course at the University of Cape Town. In the past, a lack of interest in the course has led to students being disengaged. This research paper aimed to identify whether the use of YouTube in the classroom had an effect on the engagement of Net Generation students. Furthermore, this research paper aimed to determine how YouTube was used in the classroom and how the students felt about the use of YouTube in the classroom.
\end{abstract}

Keywords: Net Generation, Higher Education, Student Engagement, Under-graduate Education, Web 2.0, YouTube, Technology-enhanced learning

\section{Introduction}

The emergence of digital technologies such as the internet and PCs has resulted in a new generation of technically literate individuals called the Net Generation (Prensky, 2001). Due to the technical literacy of these individuals, their learning styles differ from previous generations. The use of YouTube and other Web 2.0 technologies in education has been suggested as a tool to engage Net Generation students (Duffy, 2008; Roodt \& De Villiers, 2011). The use of YouTube in education is a relatively new field of study and not much literature has been published regarding the subject (Snelson, 2011).

For the purposes of this research paper, specific course was used to conduct the research. "IT in Business" (INF2004F), is a second/third year undergraduate course offered by the Department of

Material published as part of this publication, either on-line or in print, is copyrighted by the Informing Science Institute. Permission to make digital or paper copy of part or all of these works for personal or classroom use is granted without fee provided that the copies are not made or distributed for profit or commercial advantage AND that copies 1) bear this notice in full and 2) give the full citation on the first page. It is permissible to abstract these works so long as credit is given. To copy in all other cases or to republish or to post on a server or to redistribute to lists requires specific permission and payment of a fee. Contact Publisher@InformingScience.org to request redistribution permission.
Information Systems (IS) at the University of Cape Town (UCT). The course is compulsory for all students majoring in accounting and finance. The course builds on from a first year level IS course, which lays the basic foundations of Information Systems. The course consists of a theoretical component as well as a practical component (Excel and Pastel). 
A new aspect to teaching this course had been adopted through the use of YouTube videos in the class. These videos brought a new approach to teaching and it is believed that the use of YouTube as a teaching tool could have an effect on the level of student engagement.

The purpose of this research was to discover if the use of YouTube in the class had an effect on student engagement. Towards the end of the semester, students enrolled in the course were given a questionnaire asking what effect the use of YouTube videos in class had on their level of engagement. Furthermore, students previously enrolled in the course were given a similar questionnaire asking them about their level of engagement with the course. By conducting a comparative analysis, this research aimed to discover what effect, if any, the use of YouTube in the class had on student engagement.

This research paper had two objectives. These were:

- To determine the effect, if any, the use of YouTube in the classroom had on engagement of Net Generation students.

- To determine how YouTube videos were used in classroom and how the students felt about the use of YouTube in the classroom.

As such, the main hypothesis for this research is as follows:

- Can YouTube be used in the classroom to support student engagement for the Net Generation of students?

This research paper begins by conducting a review on the literature of the main topics of this research. The next section focuses on the research methodology used to achieve the objectives of the research. Then follows the data analysis, the findings of the research and finally, the conclusion.

\section{Literature Review}

\section{The Net Generation}

The Net Generation, also known as the Millennials, Generation Y and the Digital Natives, is the term used to describe the generation born between 1982 and 2003 (Berk, 2009b). This group, which will be referred to as the Net Generation throughout this paper, grew up with the digital technology that arrived in the last decades of the 20th century (Prensky, 2001). The term Net Generation was first mentioned by Tapscott (1997). The term Net Generation comes from the fact that members of this generations' birth coincided with the emergence of the Internet and digital technology (Berk, 2009b).

Members of the Net Generation have grown up with computers and the Internet and are said to have a natural aptitude and high skill levels when using new technologies (Jones, Ramanau, Cross, \& Healing, 2010). Prensky (2001) used the term "Digital Natives" to describe this group as he stated that members of this generation were so accustomed to using digital technology that they speak the digital language.

Berk (2009b) noted that defining and labelling groups of people and ascribing characteristics to them can lead to problems of misrepresentation and generalisation. Various studies (Jones et al, 2010; Kennedy, Judd, Dalgarno, \& Waycott, 2010; Margaryan, Littlejohn, \& Vojt, 2011) have shown that the Net Generation is not homogenous in their use of technology and thus some of the assumptions made about the Net Generation are not entirely true.

Growing up with and being surrounded by technology has shaped the way in which members of the Net Generation learn and participate in the classroom (Berk, 2009b; Duffy, 2008; Jones et al, 
2010; Oblinger \& Oblinger, 2005; Prensky, 2001). Educating the Net Generation has become a challenge as engaging students from the Net Generation has become difficult (Berk, 2009b; Merlino \& Rhodes, 2012).

Oblinger \& Oblinger (2005) have noted several characteristics of the Net Generation that have an impact on higher education institutions. These characteristics are (Oblinger \& Oblinger, 2005, p. $10)$ :

- Digitally Literate - the Net Generation interacts with technology on a regular basis and feels comfortable using technology

- Connected - they have access to and are connected to a technological network such as a cell phone network or social network

- Immediate - they expect immediate responses from technology and often multitask

- Experiential - they prefer to learn by doing and prefer practical learning environments

- Social - they are comfortable sharing personal information and interact with one another across various platforms

- Teams - they prefer to learn and work in teams

- Structure - they prefer structure as opposed to ambiguity in their learning

- Engagement and Experience - they prefer interactivity and interactive teaching materials

- Visual and Kinesthetic - they prefer visual teaching materials such as images as opposed to static teaching materials such as notes

- Things that Matter - they prefer to learn about issues that matter, such as environmental and economic concerns

In order to educate and engage the Net Generation, various suggestions have been made. A popular suggestion of educating and engaging the Net Generation is the use of various Web 2.0 elements in the classroom (Agazio \& Buckley, 2009; Berk, 2009a; Berk, 2009b; Duffy, 2008; Hrastinski \& Aghaee, 2011; Merlino \& Rhodes, 2012; Oblinger \& Oblinger, 2005). Other suggestions include adapting teaching methods (Wilson \& Gerber, 2008). Merlino and Rhodes (2012) suggested that teaching strategies for Net Generation students include using real world examples, creating participatory activities (projects, group work) and providing clear structure.

It is important to note that while suggestions have been made as to how to educate and engage the Net Generation, Berk (2009b) noted that generalisation of a generation and its characteristics can be limiting. The suggestion that members of the Net Generation have a different learning style has been challenged by Margaryan et al (2011). Furthermore, Jones et al (2010) and Kennedy et al (2010) suggested that the Net Generation is not necessarily homogenous in their use of technology and that skill and comfort level with technology differs within the generation.

\section{YouTube@}

YouTube is a well-known video sharing website where users can upload, view and share video clips (Duffy, 2008). YouTube was launched in 2005 and is a repository for user-generated content. Content on YouTube includes music videos, TV clips and personal videos uploaded by users, who are mainly members of the public. Videos can be viewed by anyone with an internet connection; however, in order to upload videos, a free user account is required (Burke, Snyder, \& Rager, 2009). Various organisations such as businesses, television broadcasters, universities, political parties and non-governmental organisations have set up YouTube channels in order to de- 
liver their message to a wider audience (Clifton \& Mann, 2011). Kim (2012) argued that YouTube has shifted from having mainly user-generated content to having professionally generated content as well.

Research into the use of YouTube in the classroom is a relatively new area of study. Snelson (2011) conducted a review of peer reviewed journal articles and conference proceedings published between 2006 and 2009 containing the word "YouTube" in the title. Of the 188 peer reviewed articles and conference proceedings, 30 came from the field of education. The use of YouTube in education has been documented in various areas such as nursing education (Agazio \& Buckley, 2009; Burke et al, 2009; Clifton \& Mann, 2011; Skiba, 2007) and higher education (Berk, 2009a; Duffy, 2008; Roodt \& De Villiers, 2011; Tan \& Pearce, 2012; Williams \& Chinn, 2010).

Berk (2009a) suggested the use of video clips embedded in multimedia presentations to improve learning in higher education classes. Berk (2009a) stated that videos can have a strong effect on the mind and senses. Berk (2009a) suggested a list of 20 potential learning outcomes to consider when using videos in the classroom. These include using videos to: grab students' attention, focus students' concentration, generate interest in the class, draw on students' imagination, improve attitude towards content and learning and to make learning fun. One of the methods of using videos in the classroom is using YouTube.

In higher education, Duffy (2008) gave some specific examples of how YouTube could be incorporated into teaching and learning. The examples included; making students create a video as a part of an assessment, record a video of a guest presenter and upload it to YouTube and use the comments functionality as a platform for discussion, have students search for videos related to questions posted at the end of lectures, showing students real world examples of material and theory covered in class and asking students to post video vignettes.

In the field of nursing education, Agazio and Buckley (2009) discussed how YouTube was used in different ways across different levels of education. At the undergraduate level, videos showing the image of nursing were easily found on YouTube. These videos were previously difficult and sometimes not possible to attain. At the postgraduate level, video clips were used in a theoretical foundation class. Furthermore, students were able to view highlights from conferences on various nursing related topics. Agazio and Buckley (2009) stated that exposure to that level of content would have been difficult without the use of the video clips. Agazio and Buckley (2009) found that the use of YouTube can offer flexibility and depth to both undergraduate and postgraduate programmes. Agazio and Buckley (2009) stated that the use of YouTube is "only limited by faculty and student creativity and imagination" (p.27).

Roodt and De Villiers (2011) conducted a study into the use of YouTube as a tool to support collaborative learning. The study was conducted on a first year IS course at the University of Pretoria. The course included a group project in which students used YouTube to create a video on how businesses can use Web 2.0 technologies amongst other tasks. From a sample of 185 students, Roodt and De Villiers (2011) found that the use of YouTube had a positive impact on the students. In addition, Roodt \& De Villiers (2011) found that YouTube was perceived as an innovative learning technology by the majority of students.

In addition to Roodt and De Villiers (2011), Williams and Chinn (2010) discussed the use of various Web 2.0 tools, including YouTube, as a part of a project. The project was in a sport management course at a public university in the North-eastern United States. The project required students to create a marketing campaign to increase attendance at a basketball game, using Web 2.0 tools. In the introduction of the project to the students, YouTube videos were used to help explain the ideas. Williams and Chinn (2010) found that in the project, students used YouTube to 
post videos highlighting the game. However, use of YouTube was limited to $22 \%$ of the 21 five member teams.

Tan and Pearce (2012) discussed the use of YouTube videos to help explain key ideas in a sociology course. Tan and Pearce (2012) used these videos in an introductory sociology course at the Foundation Centre at Durham University. The videos were used to illustrate important topics and were followed by explanation and discussion in the class and in smaller group environments. The videos were used to introduce key sociologists, illustrate key issues in an engaging manner and provide comic relief while still reinforcing key concepts. Tan and Pearce (2012) found that the use of YouTube videos helped students and was seen as an effective way of supporting their learning.

\section{Student Engagement}

Student engagement, according to Axelson and Flick (2011), refers to "how involved or interested students appear to be in their learning and how connected they are to their classes, their institutions, and each other" (p.38). The roots of student engagement theory can be traced back as far as 70 years ago according to Axelson and Flick (2011), to Ralph Tyler's research conducted in the 1930s into the amount of time students spent on work and its effect on learning. Student engagement theory also has its roots in the research of C. Robert Pace conducted in the 1960s and 1980s, which focused on quality of effort. Additionally, student engagement theory has its roots in the research of Alexander Astin conducted in the 1980s, which focused on students' involvement (Axelson \& Flick, 2011; Pike, 2006).

Within the field of student engagement, Fredericks, Blumenfeld and Paris (2004) discussed the three different dimensions of student engagement. The three dimensions discussed were behavioural engagement, emotional engagement and cognitive engagement.

Behavioural engagement entails positive conduct, involvement, effort and participation (Fredericks et al, 2004). Axelson and Flick (2011) added that behavioural engagement was action on the part of the student that could be observed.

Emotional engagement refers to students' affective reactions such as interest, enjoyment or a sense of belonging or comfort (Fredericks et al, 2004).

Cognitive engagement stresses investment in learning and involves self-regulation and being strategic (Fredericks et al, 2004). Finn and Zimmer (2012) added that cognitive engagement is when students go beyond the minimal requirements, and can be used to facilitate learning of complex material. Finn and Zimmer (2012) stated that going beyond the minimal requirements includes getting clarification for concepts by asking questions, persisting with difficult tasks and reading extra material over and above the prescribed material.

\section{Web 2.0}

Web 2.0 is a term used to describe technologies and applications that place an increased emphasis on user generated content, data and content sharing and collaborative effort (Harris \& Rea, 2010). Web 2.0 also describes new ways of interacting with web applications as well as the use of the web as a social platform to generate, consume and reposition content (Harris \& Rea, 2010). The term Web 2.0 was introduced by O'Reilly (2005).

Web 2.0 tools, as mentioned above, encourage sharing and collaboration. Examples of Web 2.0 tools includes blogs, wikis, podcasts, instant messaging, social networks virtual worlds, RSS feeds and social bookmarking as well as websites such as YouTube (Duffy, 2008; Harris \& Rea, 2010; Hazari, North, \& Moreland, 2010). 
The use of various Web 2.0 tools in higher education has been suggested and researched by several authors (Baxter, Connolly, Stansfield, Tsvetkova, \& Stoimenova, 2011; Churchill, 2009; Cole, 2009; Duffy, 2008; Grosseck, 2009; Harris \& Rea, 2010; Hazari et al, 2010; Virkus, 2008; Williams \& Chinn, 2010). From these studies the main Web 2.0 technologies that were suggested and researched for use in higher education were blogs, wikis, podcasts and social networks. This section discussed the two technologies that were used the most. These were blogs and wikis.

\section{Summary}

This literature review discussed the main themes of this research paper. The themes discussed were the Net Generation, YouTube, student engagement and Web 2.0. The following was found on each of these topics.

Based on the literature reviewed, it was found that the Net Generation refers to the generation born after 1982 (Prensky, 2001) around the same time as the emergence of digital technology (Berk, 2009b). Due to this fact, this group is seen as being technologically literate. Furthermore, the learning preferences of this group differ from previous generations. The literature found that Net Generation students prefer immediate responses, active participation, social environments, teamwork, structure, engaging visual aids and learning about things that matter (Oblinger \& Oblinger, 2005).

From the literature reviewed, it was noted that academic research on YouTube is a relatively new topic (Snelson, 2011). The use of YouTube in education was discussed in nursing education and higher education. The literature reviewed found that YouTube was used in education to help explain concepts in class, give real world examples of theoretical concepts and as a tool in an assessment (Agazio \& Buckley, 2009; Duffy, 2008; Roodt \& De Villiers, 2011).

Student engagement was defined as how involved and interested students are in their work (Axelson \& Flick, 2011). Three different dimensions of student engagement were discussed. These were; behavioural, emotional and cognitive (Fredricks, Blumenfeld, \& Paris, 2004). The use of YouTube as a tool for student engagement was also discussed. The literature reviewed found that YouTube can be used as a tool to increase student engagement through the use of discussions on videos and by showing real world examples of theoretical concepts (Duffy, 2008; Sherer \& Shea, 2011; Smith, 2011).

The use of blogs and wikis, two popular Web 2.0 tools, in education was also discussed. It was found that blogs and wikis were used by academics and by students. The main usage of these tools included course administration, sharing and collaborating resources and use as a platform for discussion (Duffy, 2008; Harris \& Rea, 2010).

\section{Research Design}

\section{Underlying Philosophy and Approach}

The underlying philosophy of this research paper was interpretive. This research paper attempted to measure the change in the level of student engagement through the use of YouTube in the classroom. This was done through measuring the level of engagement with YouTube and comparing it with the level of engagement without YouTube.

The underlying purpose of this research was exploratory as the research was attempting to discover what the effect of using YouTube in the classroom has on student engagement. The research was done in the South African context and thus sought new insights into the use of YouTube in education. 
The research approach was deductive and inferential. This research was not attempting to develop a theory on the use of YouTube in the classroom. Rather, the research attempted to discover if the use of YouTube in the classroom had a positive effect on student engagement as the literature suggested.

As the underlying philosophy of the research was interpretive, the data that was gathered was quantitative and qualitative in nature.

The research was being conducted at a single point in time; so thus, the research timeframe was cross sectional.

\section{Sampling}

As the research that was conducted was a comparative study, data was collected from two samples. The first sample was students currently enrolled in the course INF2004F. Students in this class were potentially part of the Net Generation. Furthermore, these students had been exposed to the use of YouTube in the classroom, thus making them the ideal sample. This sample was referred to as the 'current sample' throughout this research.

The second sample was students who have previously been enrolled in the course INF2004F. These were students currently enrolled in ACC3009W, Financial Reporting 3. Students from this course were the highest population of previously enrolled INF2004F students available to the researcher. As with the students currently enrolled in the course, students from this sample were potentially part of the Net Generation. However, as far as the knowledge of the researcher was concerned, these students were not exposed to the use of YouTube in INF2004F lectures. This sample was referred to as the 'previous sample' throughout this research.

\section{Data Collection}

Data was collected from the two sample groups in the form of an online questionnaire. The questionnaire was conducted on Vula, an education system used at the University of Cape Town.

The questionnaire was preceded by a declaration assuring the respondents that data would be kept confidential and anonymous. The questionnaire was split up into four sections, covering the four main themes of this research paper. Three of the sections (Net Generation, YouTube and Other Web 2.0 tools) in the questionnaire were the same across both samples while the fourth (Student Engagement) differed slightly.

The data that the questionnaire obtained was quantitative and qualitative in nature. 5 point Likert scales were used throughout the questionnaire. Open ended questions were also included to allow respondents to express ideas that were difficult to place on a Likert scale.

The questionnaire for the first sample of students was put up on the INF2004F Vula site towards the end of the first semester. The questionnaire received 156 responses of 616 students, which showed a response rate of $25 \%$.

The questionnaire for the second sample of students was put up on a specially created Vula site in the middle of the second semester. The participants of this site were students enrolled in ACC $3009 \mathrm{~W}$. A class list was obtained from the ACC $3009 \mathrm{~W}$ course convenor and the students added to the Vula site. The questionnaire received 85 responses of 488 students, which showed a response rate of $17 \%$.

This research paper focuses on 11 questions contained in the questionnaire. 


\section{Data Analysis}

Once the data had been collected from the sample groups, the results were exported into Microsoft Excel for the quantitative data and PDF for the qualitative data. Before the data could be analysed the data needed to be cleaned. This included removing incomplete responses and responses that were clearly filled in incorrectly. Once the data had been cleaned, the current sample consisted of 104 responses $\left(n_{c}=104\right)$ and the previous sample consisted of $70\left(n_{p}=70\right)$. Thus, the total sample consisted of 174 responses $(\mathrm{N}=174)$. Furthermore, the quantitative data needed to be changed from words into numbers before any statistical tests could be run. Each scale used in the questionnaire was given a numerical legend and each question turned into a variable name.

\section{Ethical Issues}

The questionnaire used included questions asking the respondents ethnicity and gender. Thus, ethical issues might have arisen as a result of these questions. However, the option "Prefer not to answer" was provided for those who did not wish to disclose this information. Furthermore, a consent form preceded the questionnaire. This consent form asked the respondents for their permission to use their data in the research. In addition, the consent form assured respondents that their data will be kept confidential and anonymous.

The questionnaire did not ask the respondents any questions in which they needed to be identified by name. All questionnaires collected were anonymous. Once the data was collected, the data files were password protected and encrypted. The data was not stored on more than 2 storage devices in order to minimize theft of the data. Once the final research report was written up, the data was not kept by the researcher on more than 1 storage device.

\section{Limitations of Research}

This research paper had a number of limitations which the author felt was necessary to disclose. The sample size, which was a total of 174 across two samples is not a large sample size given the total number of students in both target groups. Furthermore, the use of YouTube in INF2004F was a new intervention and thus, the full effect of using YouTube in the classroom might not be discovered in this research.

\section{Data Analysis}

For the analysis, the responses from each question were tabulated and discussed. Where questions were the same amongst both samples, the responses were not tabulated separately. Rather, the responses were tabulated together and marked as 'Current' for the current sample of students and 'Previous' for the previous sample of students. Furthermore, when responses showed little or no variation in responses, no table was used.

\section{Net Generation}

Question 1: Were you born between 1982 and 1994?

All respondents in both samples answered that they were born between 1982 and 1994.

Question 2: What is your gender?

\begin{tabular}{|l|r|r|r|r|}
\hline \multirow{2}{*}{ Gender } & \multicolumn{2}{|c|}{ Current } & \multicolumn{2}{c|}{ Previous } \\
\cline { 2 - 5 } & Resp. & $\%$ & Resp. & $\%$ \\
\hline Male & 51 & $49.04 \%$ & 21 & $30.00 \%$ \\
\hline
\end{tabular}




\begin{tabular}{|l|r|r|r|r|}
\hline Female & 53 & $50.96 \%$ & 48 & $68.57 \%$ \\
\hline PNA & 0 & $0.00 \%$ & 1 & $1.43 \%$ \\
\hline Total & $\mathbf{1 0 4}$ & $\mathbf{1 0 0 . 0 0 \%}$ & $\mathbf{7 0}$ & $\mathbf{1 0 0 . 0 0 \%}$ \\
\hline
\end{tabular}

Females made up the bulk of respondents in both samples. Only one respondent, from the previous sample, chose not to disclose their gender.

Question 3: What is your ethnicity?

\begin{tabular}{|l|r|r|r|r|}
\hline \multirow{2}{*}{ Ethnicity } & \multicolumn{2}{|c|}{ Current } & \multicolumn{2}{|c|}{ Previous } \\
\cline { 2 - 5 } & Resp. & \% & Resp. & $\%$ \\
\hline White & 22 & $21.15 \%$ & 28 & $40.00 \%$ \\
\hline Black & 52 & $50.00 \%$ & 20 & $28.57 \%$ \\
\hline Coloured & 13 & $12.50 \%$ & 5 & $7.14 \%$ \\
\hline Indian & 10 & $9.62 \%$ & 14 & $20.00 \%$ \\
\hline Asian & 1 & $0.96 \%$ & 1 & $1.43 \%$ \\
\hline Other & 2 & $1.92 \%$ & 0 & $0.00 \%$ \\
\hline PNA & 4 & $3.85 \%$ & 2 & $2.86 \%$ \\
\hline Total & $\mathbf{1 0 4}$ & $\mathbf{1 0 0 . 0 0 \%}$ & $\mathbf{7 0}$ & $\mathbf{1 0 0 . 0 0 \%}$ \\
\hline
\end{tabular}

Black and White were the ethnicity of most of the students across both samples. Most of the current sample was Black while the most of the previous sample was White. Within both samples 6 students chose not to disclose their ethnicity.

Question 4: Are you digitally literate meaning, do you interact with technological devices such as cell phones, computers, laptops or tablet PCs on a regular basis?

Within both samples, all respondents answered that they were digitally literate.

Question 5: How many hours per week do you spend interacting with technological devices?

\begin{tabular}{|l|r|r|r|r|}
\hline \multirow{2}{*}{$\begin{array}{l}\text { Interaction } \\
\text { Time } \\
\text { (hours/week) }\end{array}$} & \multicolumn{2}{|c|}{ Current } & \multicolumn{2}{l|}{ Previous } \\
\cline { 2 - 5 } & Resp. & \multicolumn{2}{l|}{ Resp. } & \multicolumn{1}{l|}{ R } \\
\hline Unsure & 13 & $12.50 \%$ & 9 & $12.86 \%$ \\
\hline $0-5$ & 8 & $7.69 \%$ & 1 & $1.43 \%$ \\
\hline $6-10$ & 9 & $8.65 \%$ & 5 & $7.14 \%$ \\
\hline $11-15$ & 18 & $17.31 \%$ & 10 & $14.29 \%$ \\
\hline $16-20$ & 21 & $20.19 \%$ & 20 & $28.57 \%$ \\
\hline $21+$ & 35 & $33.65 \%$ & 25 & $35.71 \%$ \\
\hline Total & $\mathbf{1 0 4}$ & $\mathbf{1 0 0 . 0 0 \%}$ & $\mathbf{7 0}$ & $\mathbf{1 0 0 . 0 0 \%}$ \\
\hline
\end{tabular}


Within both samples more than half of the respondents said that they spent more than 15 hours per week interacting with technological devices. Over 33\% in both samples said that they spent more than 21 hours a week interacting with technological devices.

\section{YouTube}

Question 6: Were YouTube videos used in the classroom?

\begin{tabular}{|l|r|r|r|r|}
\hline \multirow{2}{*}{$\begin{array}{l}\text { YouTube videos in class? } \\
\text { used }\end{array}$} & \multicolumn{2}{|c|}{ Current } & \multicolumn{2}{|c|}{ Previous } \\
\cline { 2 - 5 } & Resp. & $\mathbf{\%}$ & Resp. & $\%$ \\
\hline Unsure & 8 & $7.69 \%$ & 19 & $27.14 \%$ \\
\hline Never & 1 & $0.96 \%$ & 30 & $42.86 \%$ \\
\hline Occasionally/Seldom & 60 & $57.69 \%$ & 20 & $28.57 \%$ \\
\hline $\begin{array}{l}\text { Frequently/Nearly Al- } \\
\text { ways }\end{array}$ & 31 & $29.81 \%$ & 1 & $1.43 \%$ \\
\hline Always/Definitely & 4 & $3.85 \%$ & 0 & $0.00 \%$ \\
\hline Total & $\mathbf{1 0 4}$ & $\mathbf{1 0 0 . 0 0 \%}$ & $\mathbf{7 0}$ & $\mathbf{1 0 0 . 0 0 \%}$ \\
\hline
\end{tabular}

Within the current sample, more than $90 \%$ of respondents said that YouTube was used in the classroom to some extent. For the current sample, most respondents claimed that YouTube was used occasionally.

Within the previous sample, nearly $43 \%$ of respondents claimed that YouTube was never used in class. Nearly $30 \%$ of respondents claimed YouTube was used occasionally while $27 \%$ were unsure.

Question 7: In lectures where YouTube videos were not used, were you engaged?

\begin{tabular}{|l|r|r|r|r|}
\hline \multirow{2}{*}{$\begin{array}{l}\text { YouTube videos used } \\
\text { in class? }\end{array}$} & \multicolumn{2}{|c|}{ Current } & \multicolumn{2}{c|}{ Previous } \\
\cline { 2 - 5 } & Resp. & $\mathbf{\%}$ & Resp. & $\%$ \\
\hline Unsure & 7 & $6.73 \%$ & 9 & $12.86 \%$ \\
\hline Never & 6 & $5.77 \%$ & 12 & $17.14 \%$ \\
\hline Occasionally/Seldom & 60 & $57.69 \%$ & 21 & $30.00 \%$ \\
\hline $\begin{array}{l}\text { Frequently/Nearly Al- } \\
\text { ways }\end{array}$ & 24 & $23.08 \%$ & 23 & $32.86 \%$ \\
\hline Always/Definitely & 7 & $6.73 \%$ & 5 & $7.14 \%$ \\
\hline Total & $\mathbf{1 0 4}$ & $\mathbf{1 0 0 . 0 0 \%}$ & $\mathbf{7 0}$ & $\mathbf{1 0 0 . 0 0 \%}$ \\
\hline
\end{tabular}

When YouTube videos were not used in class, most respondents in the current sample were engaged occasionally. Approximately $23 \%$ were engaged frequently while just fewer than $7 \%$ were always engaged when no videos were used in class.

Within the previous sample, $30 \%$ of respondents were occasionally engaged and nearly $33 \%$ were engaged frequently when no videos were used. Slightly more than $7 \%$ were always engaged while slightly over $17 \%$ were never engaged when no videos were used in class. 
Question 8: How was YouTube used in the classroom?

\begin{tabular}{|l|r|r|r|r|}
\hline \multirow{2}{*}{$\begin{array}{l}\text { Use of YouTube in } \\
\text { class: }\end{array}$} & \multicolumn{2}{|c|}{ Current } & \multicolumn{2}{c|}{ Previous } \\
\cline { 2 - 5 } & Resp. & $\%$ & Resp. & $\%$ \\
\hline N/A & 6 & $5.77 \%$ & 41 & $58.57 \%$ \\
\hline To explain concepts & 13 & $12.50 \%$ & 2 & $2.86 \%$ \\
\hline To introduce concepts & 28 & $26.92 \%$ & 3 & $4.29 \%$ \\
\hline To illustrate concepts & 57 & $54.81 \%$ & 22 & $31.43 \%$ \\
\hline $\begin{array}{l}\text { As a part of an as- } \\
\text { sessment }\end{array}$ & 0 & $0.00 \%$ & 2 & $2.86 \%$ \\
\hline Total & $\mathbf{1 0 4}$ & $\mathbf{1 0 0 . 0 0 \%}$ & $\mathbf{7 0}$ & $\mathbf{1 0 0 . 0 0 \%}$ \\
\hline
\end{tabular}

The most common use of YouTube in the classroom, across both samples, was to illustrate concepts. Within the current sample, YouTube was also used approximately $27 \%$ of the time to introduce concepts and $12.5 \%$ of the time to explain concepts.

Within the previous sample, the most responses were for N/A. This was done as the survey asked students to choose N/A if YouTube videos had never been used in class. YouTube was used slightly over $10 \%$ to explain and introduce concepts and as a part of an assessment.

Question 9: Did the YouTube videos engage you in the classroom? (CURRENT STUDENTS ON$L Y)$

\begin{tabular}{|l|r|r|}
\hline $\begin{array}{l}\text { Engagement in the class } \\
\text { with YouTube }\end{array}$ & Resp. & $\%$ \\
\hline Unsure & 4 & $3.85 \%$ \\
\hline Never & 7 & $6.73 \%$ \\
\hline Occasionally/Seldom & 26 & $25.00 \%$ \\
\hline Frequently/Nearly Always & 45 & $43.27 \%$ \\
\hline Always/Definitely & 22 & $21.15 \%$ \\
\hline Total & $\mathbf{1 0 4}$ & $\mathbf{1 0 0 . 0 0 \%}$ \\
\hline
\end{tabular}

Within the current sample $64 \%$ of respondents said that they were at least frequently engaged by the YouTube videos in class. $25 \%$ of respondents were occasionally engaged while $7 \%$ were never engaged. 
Question 10: The use of YouTube videos? (CURRENT STUDENTS ONLY)

\begin{tabular}{|l|r|r|r|r|r|r|}
\hline & \multicolumn{2}{|l|}{$\begin{array}{l}\text { Q10.1 Increased } \\
\text { my attendance of } \\
\text { lectures }\end{array}$} & \multicolumn{2}{l|}{$\begin{array}{l}\text { Q10.2 Increased } \\
\text { my attention in } \\
\text { class }\end{array}$} & \multicolumn{2}{l|}{$\begin{array}{l}\text { Q10.3 Increased } \\
\text { my effort in class }\end{array}$} \\
\hline & \multicolumn{1}{|c|}{ Resp. } & $\%$ & Resp. & $\%$ & Resp. & $\%$ \\
\hline $\begin{array}{l}\text { Strongly } \\
\text { Disagree }\end{array}$ & 9 & $8.65 \%$ & 2 & $1.92 \%$ & 1 & $0.96 \%$ \\
\hline Disagree & 24 & $23.08 \%$ & 12 & $11.54 \%$ & 15 & $14.42 \%$ \\
\hline Neutral & 39 & $37.50 \%$ & 16 & $15.38 \%$ & 48 & $46.15 \%$ \\
\hline Agree & 21 & $20.19 \%$ & 54 & $51.92 \%$ & 35 & $33.65 \%$ \\
\hline $\begin{array}{l}\text { Strongly } \\
\text { Agree }\end{array}$ & 11 & $10.58 \%$ & 20 & $19.23 \%$ & 5 & $4.81 \%$ \\
\hline Total & $\mathbf{1 0 4}$ & $\mathbf{1 0 0 . 0 0 \%}$ & $\mathbf{1 0 4}$ & $\mathbf{1 0 0 . 0 0 \%}$ & $\mathbf{1 0 4}$ & $\mathbf{1 0 0 . 0 0 \%}$ \\
\hline
\end{tabular}

Within the current sample, approximately $30 \%$ of respondents said that the use of YouTube videos increased their attendance of lectures to some extent. Slightly more than $31 \%$ of students disagreed to some extent that the use of YouTube increased their attendance of lectures.

Furthermore, slightly more than $71 \%$ of students agreed to some extent that the use of YouTube increased their attention in class with approximately $13 \%$ disagreeing to some extent.

The use of YouTube increased effort of students in class by 38\% to some extent. Almost half the respondents were neutral on whether the use of YouTube increased their effort in class.

\begin{tabular}{|l|r|r|r|r|}
\hline & \multicolumn{2}{|l|}{$\begin{array}{l}\text { Q10.4 Do you feel that } \\
\text { the use of YouTube } \\
\text { was successful in } \\
\text { class? }\end{array}$} & $\begin{array}{l}\text { Q10.5 Would you } \\
\text { recommend the use } \\
\text { of YouTube in other } \\
\text { courses? }\end{array}$ \\
\hline & Resp. & $\%$ & Resp. & $\%$ \\
\hline $\begin{array}{l}\text { Strongly } \\
\text { Disagree }\end{array}$ & 3 & $2.88 \%$ & 4 & $3.85 \%$ \\
\hline Disagree & 6 & $5.77 \%$ & 6 & $5.77 \%$ \\
\hline Neutral & 29 & $27.88 \%$ & 24 & $23.08 \%$ \\
\hline Agree & 50 & $48.08 \%$ & 44 & $42.31 \%$ \\
\hline $\begin{array}{l}\text { Strongly } \\
\text { Agree }\end{array}$ & 16 & $15.38 \%$ & 26 & $25.00 \%$ \\
\hline Total & 104 & $\mathbf{1 0 0 . 0 0 \%}$ & $\mathbf{1 0 4}$ & $\mathbf{1 0 0 . 0 0 \%}$ \\
\hline
\end{tabular}

Within the current sample, slightly more than half the respondents agreed to some extent that the use of YouTube was successful in class. Furthermore, $65 \%$ of respondents agreed that they would recommend the use of YouTube in other courses. 
Question 11: Do you think you would have been more engaged if YouTube videos were more extensively used in class? (PREVIOUS STUDENTS ONLY)

\begin{tabular}{|l|r|r|}
\hline $\begin{array}{l}\text { Engagement if YouTube } \\
\text { had been used more ex- } \\
\text { tensively }\end{array}$ & Resp. & $\%$ \\
\hline Yes & 50 & $71.43 \%$ \\
\hline No & 20 & $28.57 \%$ \\
\hline Total & $\mathbf{7 0}$ & $\mathbf{1 0 0 . 0 0 \%}$ \\
\hline
\end{tabular}

\section{Findings}

The literature reviewed defined the Net Generation as the generation born between 1982 and 2003 (Berk, 2009b). Thus, looking at the findings of Q1 of the questionnaire, all respondents across both samples are members of the Net Generation according to Berk's (2009b) definition.

Furthermore, Oblinger \& Oblinger (2005) discussed a list of characteristics that the Net Generation possessed. Within the questionnaire, Q6 to Q16 aimed to identify if the students surveyed possessed these characteristics. The results are discussed below.

With regards to being digitally literate, connected and social, the findings confirmed that all respondents across both samples described themselves as being digitally literate. Furthermore, all the respondents in both samples were connected to some form of technological network and a vast majority were members of social networks.

Thus, in answering RQ1, the research has found that the students surveyed are Net Generation students. All of the respondents were born after 1982. Furthermore, majority of the students possessed almost all of the characteristics noted by Oblinger \& Oblinger (2005).

In trying to achieve the first objective of the research, the discussion has established that the students surveyed were Net Generation students and that YouTube had been used in class. What remains to be established is whether the use of YouTube in class had an effect on overall engagement and the different types of engagement.

Looking at the findings, $58 \%$, in the current sample said that they were occasionally engaged in lectures where no YouTube videos were used. Nearly $23 \%$ said that they were frequently engaged while only $6 \%$ said that they were never engaged when no YouTube videos were used. When comparing the findings for the current sample, one can see that $64 \%$ of respondents said that the YouTube videos had engaged them at least frequently. Thus, on the surface it appears that the use of YouTube videos had a positive effect on engagement.

\section{Conclusion}

This research had two objectives. In order to achieve these objectives, students across two samples were surveyed through the use of an online questionnaire. The results of this questionnaire were analysed and compared to literature reviewed.

The first of these objectives was to determine the effect, if any, the use of YouTube in the classroom had on engagement of Net Generation students. In order to achieve this objective, the research needed to identify whether the students surveyed were a part of the Net Generation, whether YouTube had been used in class and whether the use of YouTube had an effect on engagement. 
The research found that the students surveyed were a fair representation of the Net Generation according to the literature reviewed. Furthermore, the extent of the use of YouTube in the classroom between the two samples was significantly different. Lastly, the research found that the use of YouTube in the classroom had a positive effect on overall engagement as well as on behavioural, emotional and cognitive engagement.

The students surveyed in this research felt that the use of YouTube in class was successful and many students recommended the use of videos in other courses.

\section{References}

Agazio, J., \& Buckley, K. (2009). An untapped resource: Using YouTube in nursing education. Nurse Educator, 34(1), 23-28.

Axelson, R., \& Flick, A. (2011). Defining student engagement. Change: The Magazine of Higher Learning, 43(1), 38-43.

Baxter, G. J., Connolly, T. M., Stansfield, M. H., Tsvetkova, N., \& Stoimenova, B. (2011). Introducing Web 2.0 in education: A structured approach adopting a Web 2.0 implementation framework. 2011 7th International Conference on Next GenerationWeb Services Practices (pp. 499-504). IEEE.

Berk, R. A. (2009a). Multimedia teaching with video clips: TV, movies, YouTube, and mtvU in the college classroom. International Journal of Technology in Teaching and Learning, 5(1), 1-21.

Berk, R. A. (2009b). Teaching strategies for the net generation. Transformative Dialogues: Teaching \& Learning Journal Volume, 3(2), 1-24.

Burke, S. C., Snyder, S., \& Rager, R. C. (2009). An assessment of faculty usage of YouTube as a teaching resource. The Internet Journal of Allied Health Sciences and Practice, 7(1), 1-8.

Chetty, M., Banks, R., Bernheim Brush, A., Donner, J., \& Grinter, R. E. (2011). While the meter is running: Computing in a capped world. Interactions, 18(2), 72-75.

Churchill, D. (2009). Educational applications of Web 2.0: Using blogs to support teaching and learning. British Journal of Educational Technology, 40(1), 179-183.

Clifton, A., \& Mann, C. (2011). Can YouTube enhance student nurse learning? Nurse Education Today, 31(4), 311-313.

Cole, M. (2009). Using Wiki technology to support student engagement: Lessons from the trenches. Computers \& Education, 52(1), 141-146.

Duffy, P. (2008). Engaging the YouTube google-eyed generation: Strategies for using Web 2.0 in teaching and learning. The Electronic Journal of e-Learning, 6(2), 119-130.

Finn, J. D., \& Zimmer, K. S. (2012). Student engagement: What is it? Why does it matter? In S. L. Christenson, A. L. Reschly, \& C. Wylie, Handbook of research on student engagement (pp. 97-131). Boston: Springer.

Fredricks, J. A., Blumenfeld, P. C., \& Paris, A. H. (2004). School engagement: Potential of the concept, state of the evidence. Review of Educational Research, 74(1), 59-109.

Grosseck, G. (2009). To use or not to use web 2.0 in higher education? Procedia - Social and Behavioral Sciences, 1(1), 478-482.

Harris, A. L., \& Rea, I. A. (2010). Web 2.0 and virtual world technologies: A growing impact on IS education. Journal of Information Systems Education, 20(2), 137-145.

Hazari, S., North, A., \& Moreland, D. (2010). Investigating pedagogical value of wiki technology. Journal of Information Systems Education, 20(2), 187-199.

Hrastinski, S., \& Aghaee, N. M. (2011). How are campus students using social media to support their studies? An explorative interview study. Education and Information Technologies, 17(4), 451-464. 
Jones, C., Ramanau, R., Cross, S., \& Healing, G. (2010). Net generation or digital natives: Is there a distinct new generation entering university? Computers \& Education, 54(3), 722-732.

Kennedy, G., Judd, T., Dalgarno, B., \& Waycott, J. (2010). Beyond natives and immigrants: exploring types of net generation students. Journal of Computer Assisted Learning, 26(5), 332-343.

Kim, J. (2012). The institutionalization of YouTube: From user-generated content to professionally generated content. Media Culture \& Society, 34(1), 53-67.

Margaryan, A., Littlejohn, A., \& Vojt, G. (2011). Are digital natives a myth or reality? University students' use of digital technologies. Computers \& Education, 56(2), 429-440.

Merlino, N., \& Rhodes, R. (2012). Technology in the 21st century classroom: Key pedagogical strategies for millennial students in university business courses. Journal of Supply Chain and Operations Management, 10(1), 113-130.

Oblinger, D., \& Oblinger, J. (2005). Educating the net generation. Boulder: EDUCASE.

O'Reilly, T. (2005, September 30). What is Web 2.0: Design patterns and business models for the next generation of software. Retrieved April 8, 2012, from O'Reilly Media: http://oreilly.com/web2/archive/what-is-web-20.html

Pike, G. R. (2006). The convergent and discriminant validity of NSSE Scalelet scores. Journal of College Student Development, 47(5), 550-563.

Prensky, M. (2001). Digital natives, Digital immigrants Part 1. On the Horizon, 9(5), 1-6.

Roodt, S., \& De Villiers, C. (2011). Using YouTube as an innovative tool for collaborative learning at undergraduate level in tertiary education. Proceedings of the AIS SIG-ED IAIM 2011 Conference.

Sherer, P., \& Shea, T. (2011). Using online video to support student learning and engagement. College Teaching, 59(2), 56-59.

Skiba, D. (2007). Nursing education 2.0: YouTube. Nursing Education Perspectives, 28(2), 100-102.

Smith, J. (2011). The YouTube revolution: Engagement, perception and identity. ICPhS XVII, (pp. 100103). Hong Kong.

Snelson, C. (2011). YouTube across the disciplines: A review of the literature. MERLOT Journal of Online Learning and Teaching, 7(1), 159-169.

Tan, E., \& Pearce, N. (2012). Open education videos in the classroom: Exploring the opportunities and barriers to the use of YouTube in teaching introductory sociology. Research in Learning Technology, $19(1), 125-133$.

Tapscott, D. (1997). Growing up digital: The rise of the net generation. New York: McGraw-Hill.

Virkus, S. (2008). Use of Web 2.0 technologies in LIS education: Experiences at Tallinn University, Estonia. Program: Electronic Library and Information Systems, 42(3), 262-274.

Williams, J., \& Chinn, S. J. (2010). Using Web 2.0 to support the active learning experience. Journal of Information Systems Education, 20(2), 165-175.

Wilson, M., \& Gerber, L. E. (2008). How generational theory can improve teaching: strategies for working with the "millennials". Currents in Teaching and Learning, 1(1), 29-44. 


\section{Biography}

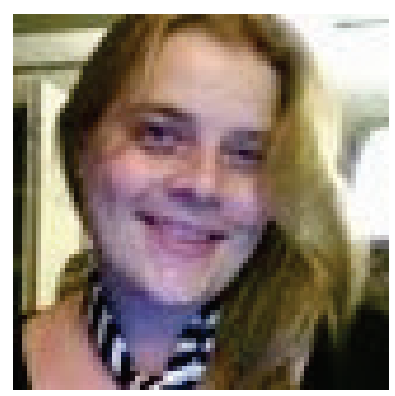

Sumarie Roodt completed her BCom: Informatics at the University of Pretoria before working in financial services for 6 years. During her time in the banking sector she performed a number of roles, including being a project manager, a strategic alliances portfolio manager and then a strategy consultant. During her time in financial services she obtained her PostGraduate Diploma in Advanced Project and Programme Management from Cranefield as well as a Banking qualification from the Chartered Institute of Bankers in London. Sumarie decided to pursue her MBA full-time at the University of Cape Town's Graduate School of Business and was then selected to attend the University of Chicago's Graduate School of Business in order to specialiaze in Entrepreneurial Finance for High-Technology Ventures. Sumarie returned to South Africa to take up a lecturing position in the Department of Informatics at the University of Pretoria for three years. She is now a full-time senior lecturer at the University of Cape Town and is currently busy with her $\mathrm{PhD}$ in Informatics which involves using social computing for computer-supported collaborative learning. Sumarie has a passion for developing teaching and learning toolkits that leverage emerging technologies in order to improve the learning experiences of the Net Generation of students and more recent generations. She has received a number of grants and awards for the research that she conducts regarding the use of technology in education. Sumarie teaches on both the under-graduate and post-graduate streams within the department and enjoys a diverse range of topics. Her research interests are technologyenhanced learning, Digital Game-Based Learning (DGBL), Virtual Worlds, Educational Neuroscience and Using emerging technologies for Competitive Advantage (IS in Organisations). Sumarie has published a number of local and international conference papers, as well as journal articles. She is also the President of the Association for Information Systems (AIS) Special Interest Group (SIG) for Education.

Dominic Peier is a full-time BCom: Information Systems Honours student at the Department of Information Systems at the University of Cape Town. Dominique has a keen interest in how technology can be used for student engagement. 